\title{
UJI BEBERAPA KONSENTRASI EKSTRAK RIMPANG JERINGAU (Acorus calamus L.) UNTUK MENGENDALIKAN HAMA WALANG SANGIT (Leptocorisa acuta Thunberg) PADA TANAMAN PADI GOGO (Oryza sativa L.)
}

\author{
Test of Some Concentrations Sweet Flag Rhizome Extract (Acorus calamus L.) \\ to Control Rice Seed Bug Pest (Leptocorisa acuta Thunberg) \\ on the Upland Rice Plant (Oryza sativa L.)
}

\author{
Desita Salbiah dan Nizwan Harefa \\ Agrotechnology Study Program, Majoring in Agrotechnology \\ Faculty of Agriculture, Riau University, Pekanbaru \\ Email: nizwanharefa@gmail.com \\ [Diterima Juli 2018; Disetujui Agustus 2018]
}

\begin{abstract}
Government efforts in supporting the increase in national rice production, namely optimizing dry land by planting upland rice. Rice seed bug (Leptocorisa acuta Thunberg) is a potential pest that at certain times become an important pest on the upland rice plants, therefore needed to control is using organic insecticide such as sweet flag rhizome extract. This research was aimed to obtain an effective concentration sweet flag rhizome extract (Acorus calamus L.) to control rice seed bug pest (Leptocorisa acuta Thunberg) on the upland rice plant (Oryza sativa L.). The research was conducted at the Experimental Garden and Plant Pest Laboratory, Faculty of Agriculture, Riau University, Pekanbaru from January to May 2018. The experimentally by using a completely randomized design (CRD), which consist of five concentration sweet flag rhizome extract treatments are 0 g.l-1 water, 20 g.l-1 water, 40 g.l-1 water, 60 g.l-1 water and 80 g.l-1 water. The treatments repeated four times, therefore, twenty experimental units. The results showed that the concentration of 80 g.l-1 water was an effective concentration to control rice seed bug with the fastest start time of death at 1,25 hours, the fastest LT50 at 30,25 hours and the total mortality rate of $87,50 \%$.
\end{abstract}

Keywords: Organic insecticide, Sweet Flag Rhizome, Rice Seed Bug, Upland Rice

\begin{abstract}
ABSTRAK
Upaya pemerintah dalam mendukung peningkatan produksi beras nasional, yaitu mengoptimalkan lahan kering dengan menanam padi gogo. Hama Walang Sangit (Leptocorisa acuta Thunberg) merupakan hama potensial yang pada waktu-waktu tertentu menjadi hama penting pada tanaman padi gogo, oleh karena itu diperlukan pengendalian yang menggunakan insektisida organik seperti ekstrak Rimpang Jeringau. Penelitian ini bertujuan untuk memperoleh konsentrasi efektif ekstrak rimpang Jeringau (Acorus calamus L.) untuk mengendalikan hama Hama Walang Sangit (Leptocorisa acuta Thunberg) pada tanaman padi gogo (Oryza sativa L.). Penelitian ini dilakukan di Laboratorium Percobaan Kebun dan Hama Tumbuhan, Fakultas Pertanian, Universitas Riau, Pekanbaru dari Januari hingga Mei 2018. Penelitian dilakukan dengan menggunakan Rancangan Acak Lengkap (RAL), yang terdiri dari lima konsentrasi ekstrak rimpang Jeringau yaitu: $0 \mathrm{gl}^{-1}$ air, 20 $\mathrm{gl}^{-1}$ air, $40 \mathrm{gl}^{-1}$ air, $60 \mathrm{gl}^{-1}$ air dan $80 \mathrm{gl}^{-1}$ air. Perawatan diulang empat kali karena itu dua puluh unit eksperimental. Hasil penelitian menunjukkan bahwa konsentrasi $80 \mathrm{gl}^{-1}$ air adalah konsentrasi yang efektif untuk mengendalikan Hama Walang Sangit dengan waktu mulai tercepat kematian pada 1,25 jam, LT tercepat 50 pada 30,25 jam dan total tingkat kematian $87,50 \%$.
\end{abstract}

Kata kunci: Insektisida organik, Rimpang Jeringau, Hama Walang Sangit, Padi Gogo 


\section{PENDAHULUAN}

Padi (Oryza sativa L.) merupakan komoditas tanaman pangan penghasil beras yang ketersediaannya diperlukan sepanjang tahun. Padi dapat tumbuh hampir pada semua jenis tanah dari yang bertopografi datar sampai miring dan $1500 \mathrm{~m}$ di atas permukaan laut (Perdana, 2010).

Peningkatan produksi padi di Indonesia tidak hanya bertumpu pada padi sawah. Upaya pemerintah dalam mendukung peningkatan produksi padi nasional yaitu mengoptimalkan lahan-lahan kering yang tersebar luas di seluruh wilayah Indonesia dengan penanaman padi gogo. Budidaya padi gogo tidak memerlukan biaya tinggi karena tidak membutuhkan infrastruktur irigasi seperti pada padi sawah dan tidak mengubah keseimbangan ekologi secara frontal (Haryanto et al., 2003).

Produksi padi gogo di Provinsi Riau tahun 2015 hanya mencapai 48,476 ton dengan tingkat produktivitas sebesar 2,273 ton.ha ${ }^{-1}$. Hasil produksi padi gogo tersebut masih belum memenuhi kebutuhan beras di Provinsi Riau. Hal ini disebabkan oleh beberapa kendala diantaranya berupa faktor biotik yaitu serangan hama (Badan Pusat Statistik Riau, 2017).

Hama yang menyerang pada tanaman padi diantaranya adalah hama walang sangit (Leptocorisa acuta Thunberg). Hama ini merupakan hama utama tanaman padi yang menyerang pada saat matang susu dengan cara menghisap bulir padi dengan menggunakan rostrumnya.

Serangan hama walang sangit yang tinggi terhadap pertanaman padi belum dapat dikendalikan dengan pengendalian yang efektif dan efisien dimana sampai saat ini petani masih menggunakan insektisida sintetik.

Penggunaan insektisida sintetik dapat diminimalisir dengan menerapkan pengendalian yang lain di antaranya penggunaan pestisida nabati yaitu tanaman jeringau (Acorus calamus L.). Bagian tanaman jeringau yang dapat digunakan sebagai pestisida nabati adalah bagian rimpangnya karena mengandung minyak atsiri sebagai bahan insektisida.

Minyak atsiri rimpang jeringau mengandung senyawa asarone yang dapat masuk ke dalam tubuh serangga sebagai racun kontak dan racun perut. Setelah masuk ke dalam tubuh serangga, senyawa ini bekerja sebagai racun saraf dengan mengganggu impuls saraf pada akson sehingga mengakibatkan kematian pada serangga (Farida, 2008).

Pemanfaatan ekstrak rimpang jeringau telah dilakukan oleh Hafiz (2013) menunjukkan konsentrasi yang efektif dalam mengendalikan Myzus persicae Sulzer $50 \mathrm{~g} / \mathrm{l}$ air (5\%) menghasilkan mortalitas total $93,33 \%$ dengan waktu awal kematian 1,75 jam setelah aplikasi.

Berdasarkan hal tersebut, maka penulis telah melakukan penelitian yang berjudul " $\mathrm{Uji}$

Beberapa Konsentrasi Ekstrak Rimpang Jeringau (Acorus calamus L.) untuk Mengendalikan Hama Walang Sangit (Leptocorisa acuta Thunberg) pada Tanaman Padi Gogo (Oryza sativa L.)".

Penelitian bertujuan untuk mendapatkan konsentrasi ekstrak rimpang jeringau (Acorus calamus L.) yang efektif untuk mengendalikan hama walang sangit (Leptocorisa acuta Thunberg) pada tanaman padi gogo (Oryza sativa $\mathrm{L}$.).

\section{METODOLOGI}

Penelitian telah dilaksanakan di Kebun Percobaan dan Laboratorium Hama Tumbuhan Fakultas Pertanian Universitas Riau, Pekanbaru. Penelitian telah dilaksanakan dari bulan Januari 2018 hingga Mei 2018.

Bahan yang digunakan yaitu rimpang jeringau, nimfa walang sangit instar dua, tanah lapisan atas, benih padi varietas Situ Patenggang, air, aquades, dan sabun krim.

Alat yang digunakan antara lain, parang, cangkul, termohygrometer, blender, pisau, saringan, baskom, gunting, hand sprayer, tempat pengaduk, gelas ukur, timbangan analitik, kotak kayu ukuran 50x50 cm sebagai tempat penyemaian tanaman padi, polybag $30 \times 40 \mathrm{~cm}$, sungkup tanaman, jaring serangga, kamera HP, SAS 9.1 dan alat tulis.

Penelitian dilaksanakan secara eskperimen dengan menggunakan rancangan acak lengkap (RAL), yang terdiri dari lima perlakuan dan empat kali ulangan sehingga diperoleh 20 unit percobaan. Setiap unit percobaan diinfestasikan sebanyak 10 ekor nimfa walang sangit. Perlakuan yang diberikan 
pada masing-masing unit percobaan adalah konsentrasi ekstrak rimpang jeringau sebagai berikut: $\mathrm{J}_{0}=$ ekstrak $0 \mathrm{~g}$ rimpang jeringau $\mathrm{l}^{-1}$ air, $\mathrm{J}_{1}=$ ekstrak $20 \mathrm{~g}$ rimpang jeringau $\mathrm{l}^{-1}$ air, $\mathrm{J}_{2}=$ ekstrak $40 \quad \mathrm{~g}$ rimpang jeringau $1^{-1}$ air, $\mathrm{J}_{3}=$ ekstrak $60 \mathrm{~g}$ rimpang jeringau $\mathrm{l}^{-1}$ air dan

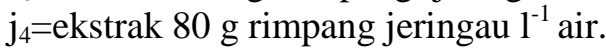

Parameter pengamatan yang diamati yaitu perubahan tingkah laku dan morfologi, waktu awal kematian, lethal time $50\left(\mathrm{LT}_{50}\right)$, mortalitas harian dan mortalitas total.

Hasil analisis sidik ragam yang berbeda nyata diuji lanjut dengan DNMRT (Duncan New Multiple Range Test) pada taraf 5\%.

\section{HASIL DAN PEMBAHASAN}

\section{Perubahan Tingkah Laku dan Morfologi Nimfa Walang Sangit}

Hasil pengamatan perubahan tingkah laku nimfa walang sangit setelah diberi perlakuan ekstrak rimpang jeringau terjadi 30 menit setelah aplikasi perlakuan yang dimulai dengan aktifitas pergerakan mulai lambat, aktifitas makan berkurang, tungkai depan selalu digesek ke antena kemudian hinggap pada bagian bawah daun, akhirnya jatuh dan mati.

Perubahan morfologi ditandai dangan perubahan warna nimfa walang sangit yang semula berwarna hijau muda perlahan-lahan berubah menjadi hijau kekuningan, kemudian menjadi kuning kecoklatan dan akhirnya berubah menjadi coklat kehitaman. Setelah itu, tubuh nimfa menjadi kaku, tidak bergerak, mengeluarkan cairan dari tubuh, kemudian mengeras dan akhirnya tubuh menjadi kering yang menandakan nimfa walang sangit tersebut telah mati. Hal ini sesuai dengan pendapat Nursal et al. (1997) menyatakan bahwa senyawa toksin yang terkandung dalam rimpang jeringau adalah senyawa asarone yang dapat menyebabkan bagian tubuh serangga menjadi kaku, sehingga aktifitas serangga akan terganggu dan mengakibatkan penurunan aktifitas metabolisme tubuh dan pencernaan serta lama-kelamaan serangga akan mati.

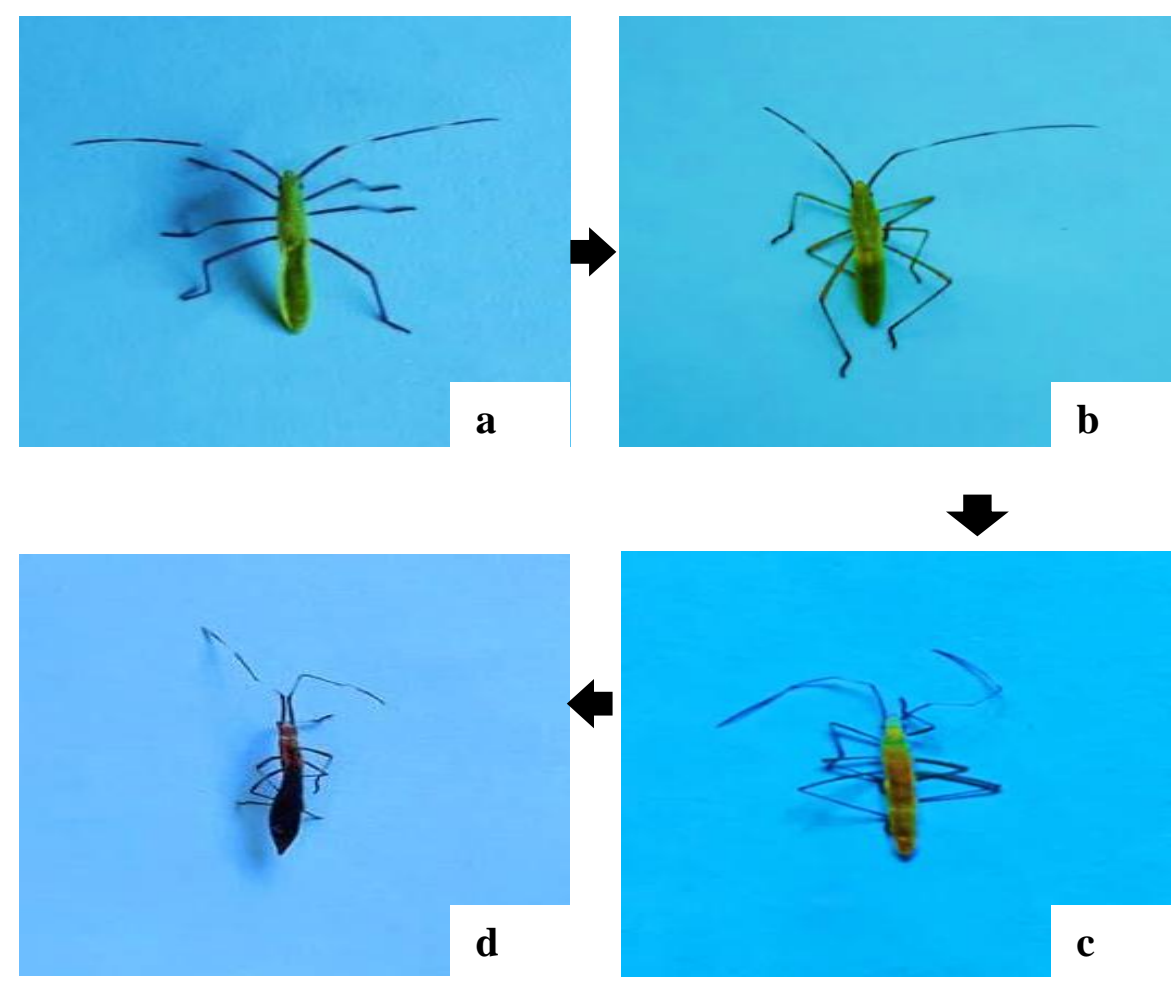

Gambar 1. Perubahan morfologi dan warna tubuh nimfa walang sangit setelah aplikasi ekstrak rimpang jeringau. (a) nimfa walang sangit sebelum aplikasi, (b) 2 jam setelah aplikasi, (c) 26 jam setelah aplikasi, (d) 52 jam setelah aplikasi (Dokumentasi penelitian, 2018) 


\section{Waktu Awal Kematian (jam)}

Hasil pengamatan awal kematian nimfa walang sangit setelah dianalisis menggunakan sidik ragam menunjukkan bahwa perlakuan dari beberapa konsentrasi ekstrak rimpang jeringau (Acorus calamus L.) memberikan pengaruh nyata terhadap waktu awal kematian nimfa walang sangit, hasil uji lanjut DNMRT pada taraf 5\% dapat dilihat pada Tabel 1.

Tabel 1 menunjukkan bahwa pemberian konsentrasi ekstrak rimpang jeringau 80 g. $l^{-1}$ air menyebabkan waktu awal kematian nimfa walang sangit tercepat yaitu 1,25 jam setelah aplikasi. Perlakuan konsentrasi 80 g. $\mathrm{l}^{-1}$ air berbeda nyata dengan semua perlakuan. Hasil penelitian Hafiz (2013) menunjukkan bahwa konsentrasi ekstrak rimpang jeringau $50 \mathrm{~g} .1^{-1}$ air menyebabkan awal kematian Myzus persicae pada 1,75 jam setelah aplikasi. Hal ini diduga senyawa aktif asarone yang terdapat di dalam ekstrak rimpang jeringau masuk ke dalam tubuh serangga sebagai racun kontak dan racun perut serta bekerja secara cepat sebagai racun saraf.

Tabel 1. Rata-rata awal kematian nimfa walang sangit dengan perlakuan beberapa konsentrasi ekstrak rimpang jeringau (jam)

\begin{tabular}{cc}
\hline $\begin{array}{c}\text { Konsentrasi ekstrak rimpang jeringau } \\
\left.\text { (g. } \text { - }^{-1} \text { air }\right)\end{array}$ & $\begin{array}{c}\text { Rata-rata waktu awal kematian nimfa walang sangit } \\
\text { (jam) }\end{array}$ \\
\hline 0 & $96,0 \mathrm{c}$ \\
20 & $6,75 \mathrm{~b}$ \\
40 & $5,75 \mathrm{~b}$ \\
60 & $4,25 \mathrm{~b}$ \\
80 & $1,25 \mathrm{a}$ \\
\hline
\end{tabular}

Angka-angka pada lajur yg diikuti oleh huruf kecil yang tidak sama berbeda nyata menurut uji DNMRT pada taraf 5\%.

Menurut Pandey et al. (2005) bahwa asarone merupakan senyawa yang dapat bersifat insektisida yang masuk sebagai racun kontak dan racun perut. Setelah masuk ke dalam tubuh serangga, senyawa kimia tersebut bekerja sebagai racun saraf sehingga dapat menghambat respirasi sel dan pernapasan terganggu sehingga menyebabkan kematian pada serangga. Hal ini sesuai dengan pendapat Tarumingkeng (1992) bahwa penghambatan pada respirasi sel menyebabkan serangga mengalami kelumpuhan alat pernapasan dan mengakibatkan disfungsional pada bagian pencernaan serta mengganggu proses metabolisme sehingga terjadi gejala inaktif, paralisis dan akhirnya mati.

Perlakuan konsentrasi ekstrak rimpang jeringau $60 \mathrm{~g} . \mathrm{l}^{-1}$ air berbeda tidak nyata dengan konsentrasi 40 g..$^{-1}$ air dan 20 g. $1^{-1}$ air. Hal ini menunjukkan bahwa peningkatan konsentrasi 20 g. $1^{-1}$ air menjadi 40 g. $1^{-1}$ air dan 40 g. $l^{-1}$ air menjadi 60 g. $1^{-1}$ air belum memberikan pengaruh yang nyata terhadap waktu awal kematian. Hal ini diduga senyawa yang terkandung dalam ekstrak rimpang jeringau belum bekerja secara maksimal sehingga dengan peningkatan konsentrasi hingga $60 \mathrm{~g} . \mathrm{l}^{-1}$ air belum menimbulkan pengaruh terhadap awal kematian nimfa walang sangit sehingga perbedaan belum terlihat nyata. Hal ini sesuai dengan pendapat Prijono (2002) reaksi pestisida nabati bekerja secara lambat sehingga waktu yang dibutuhkan untuk mematikan serangga uji juga lambat.

Perbedaan waktu awal kematian ini diduga karena konsentrasi yang diberikan pada setiap perlakuan berbeda-beda, semakin tinggi konsentrasi yang diberikan maka senyawa asarone yang terdapat pada ekstrak rimpang jeringau semakin tinggi yang mengakibatkan semakin banyak pula senyawa yang masuk pada tubuh nimfa walang sangit. Hal ini sesuai dengan pernyataan Aminah (1995) bahwa tinggi rendahnya suatu konsentrasi akan mempengaruhi kandungan bahan aktif dan berpengaruh terhadap awal kematian serangga uji.

\section{Lethal Time (LT $\left.\mathbf{T}_{50}\right)(\mathrm{jam})$}

Hasil pengamatan untuk mematikan nimfa walang sangit sebanyak 50\% (lethal time 50) setelah dianalisis menggunakan sidik ragam menunjukkan bahwa perlakuan konsentrasi ekstrak rimpang jeringau (Acorus calamus L.) memberikan pengaruh nyata terhadap waktu 
Uji Beberapa Konsentrasi Ekstrak Rimpang Jeringau (Acorus calamus L.) untuk Mengendalikan Hama Walang Sangit (Leptocorisa acuta Thunberg) pada Tanaman Padi Gogo (Oryza sativa L.)

yang dibutuhkan ekstrak rimpang jeringau untuk mematikan nimfa walang sangit sebanyak
50\%, hasil uji lanjut DNMRT pada taraf 5\% dapat dilihat pada Tabel 2.

Tabel 2. Rata-rata lethal time 50 nimfa walang sangit dengan perlakuan beberapa konsentrasi ekstrak rimpang jeringau (jam)

\begin{tabular}{|c|c|}
\hline $\begin{array}{l}\text { Konsentrasi ekstrak rimpang jeringau } \\
\left(\mathrm{g} . \mathrm{l}^{-1} \text { air }\right)\end{array}$ & Rata-rata lethal time 50 nimfa walang sangit (jam) \\
\hline 0 & $96 \mathrm{~d}$ \\
\hline 20 & $79,25 \mathrm{c}$ \\
\hline 40 & $59,00 \mathrm{~b}$ \\
\hline 60 & $53,00 \mathrm{~b}$ \\
\hline 80 & $30,25 \mathrm{a}$ \\
\hline
\end{tabular}

Angka-angka pada lajur yg diikuti oleh huruf kecil yang tidak sama berbeda nyata menurut uji DNMRT pada taraf 5\%.

Tabel 2 menunjukkan bahwa perlakuan konsentrasi ekstrak rimpang jeringau $80 \mathrm{~g} . \mathrm{l}^{-1}$ air merupakan konsentrasi dengan waktu tercepat dalam mematikan $50 \%$ nimfa walang sangit yaitu 30,25 jam setelah aplikasi. Perlakuan konsentrasi 80 g..$^{-1}$ air berbeda nyata dengan semua perlakuan. Hal ini berkaitan pada Tabel 1 bahwa konsentrasi 80 g..$^{-1}$ air menunjukkan awal kematian nimfa walang sangit paling cepat sehingga mengakibatkan $\mathrm{LT}_{50}$ (Tabel 2) juga semakin cepat. Hal ini sesuai dengan pendapat Dewi (2010) bahwa suatu konsentrasi yang tinggi memiliki kandungan bahan aktif yang tinggi pula maka pengaruh yang ditimbulkan terhadap kematian serangga uji juga semakin tinggi, di samping itu daya kerja suatu bahan sangat ditentukan oleh tingginya konsentrasi.

Hasil penelitian Hafiz (2013) menunjukkan bahwa konsentrasi ekstrak rimpang jeringau 50 g. $\mathrm{l}^{-1}$ air menghasilkan $\mathrm{LT}_{50}$ Myzus persicae pada 28,50 jam setelah aplikasi. Sedangkan $\mathrm{LT}_{50}$ nimfa walang sangit dengan konsentrasi ekstrak rimpang jeringau 80 g. $\mathrm{l}^{-1}$ cenderung lebih lama yaitu 30,25 jam setelah aplikasi. Hal ini diduga berkaitan dengan ukuran tubuh serangga yang berbeda. Menurut Dadang dan Prijono (2008) bahwa serangga yang berukuran lebih besar sering lebih tahan terhadap senyawa bioaktif dari pada serangga yang berukuran kecil. Pada serangga kecil, senyawa bioaktif dapat lebih cepat mencapai dan memenuhi bagian sasaran dalam konsentrasi yang cukup menimbulkan kematian dibandingkan pada serangga yang lebih besar.

Perlakuan konsentrasi 60 g. $1^{-1}$ air $(53$ jam) berbeda tidak nyata dengan perlakuan konsentrasi 40 g..$^{-1}$ air (59 jam). Hal ini diduga perlakuan $60 \mathrm{~g} . \mathrm{l}^{-1}$ air memberikan respon yang sama dalam membunuh 50\% nimfa walang sangit dengan perlakuan $40 \mathrm{~g}^{-1} \mathrm{l}^{-1}$ air. Perlakuan konsentrasi ekstrak rimpang jeringau 20 g. $\mathrm{l}^{-1}$ air (79,25 jam) menunjukkan pengaruh yang berbeda nyata dengan konsentrasi 40 g. $1^{-1}$ air (59 jam). Hal ini berbeda pada waktu awal kematian (Tabel 1) dimana konsentrasi 20 g.l ${ }^{-1}$ air dan 40 g. $l^{-1}$ air menunjukkan pengaruh hasil yang berbeda tidak nyata. Hal ini dikarenakan konsentrasi yang rendah menyebabkan bahan aktif asarone bekerja secara lambat sehingga pada waktu awal kematian bahan aktif belum bekerja secara maksimal untuk mematikan nimfa walang sangit. Hal ini sesuai dengan Syakir (2011) menyatakan bahwa kendala dalam penggunaan pestisida nabati adalah pestisida nabati tidak dapat bereaksi cepat dan relatif lambat dalam mematikan hama.

Daya kerja senyawa yang terdapat pada kedua perlakuan konsentrasi tersebut pada $\mathrm{LT}_{50}$ sudah mulai bekerja dengan maksimal sehingga menyebabkan $\mathrm{LT}_{50}$ nimfa walang sangit yang berbeda nyata. Selain itu, pada $\mathrm{LT}_{50}$ senyawa asarone yang masuk sebagai racun kontak dan racun perut ke dalam tubuh walang sangit telah terakumulasi dengan baik. Hal ini sesuai dengan pendapat Farida (2008) bahwa semakin banyak senyawa yang masuk pada tubuh serangga, maka senyawa tersebut akan menstimulasi kemoreseptor untuk dilanjutkan ke sistem saraf serangga sehingga aktifitas serangga terganggu dan menyebabkan serangga berhenti makan akibatnya serangga lemah dan akhirnya mati. 


\section{Mortalitas Harian (\%)}

Hasil pengamatan mortalitas harian terhadap nimfa walang sangit dengan perlakuan konsentrasi ekstrak rimpang jeringau yang berbeda menunjukkan pengaruh terhadap kematian nimfa walang sangit. Persentase mortalitas harian nimfa walang sangit dapat dilihat pada Gambar 2.

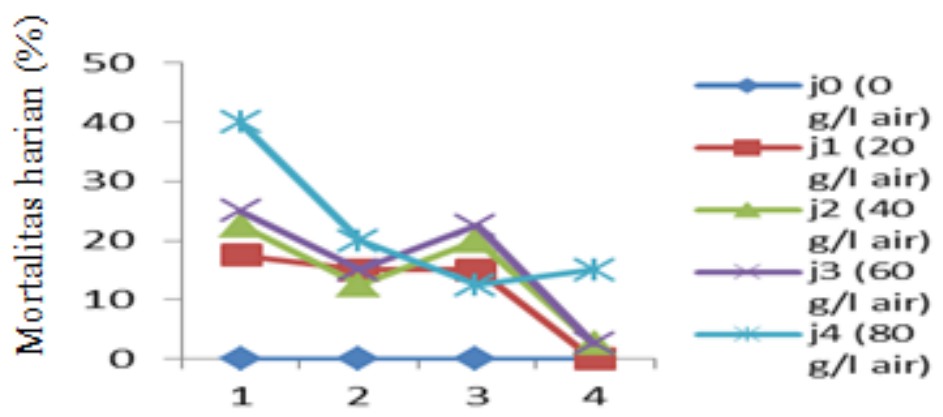

Hari setelah aplikasi

Gambar 2. Fluktuasi mortalitas harian nimfa walang sangit setelah aplikasi beberapa konsentrasi ekstrak rimpang jeringau

Gambar 2 menunjukkan fluktuasi mortalitas harian nimfa walang sangit pada setiap perlakuan. Perlakuan ekstrak rimpang jeringau mampu menyebabkan puncak mortalitas harian nimfa walang sangit pada hari pertama dan semua perlakuan telah mampu mematikan nimfa walang sangit pada kisaran $17,5-40 \%$ kecuali pada perlakuan 0 g..$^{-1}$ air. Hal ini diduga karena senyawa asarone yang terkandung dalam ekstrak rimpang jeringau bersifat toksik tinggi yang masuk sebagai racun kontak dan racun perut dan bekerja secara maksimal sebagai racun saraf.

Mortalitas harian pada hari pertama terlihat bahwa perlakuan konsentrasi 80 g. $l^{-1}$ air merupakan konsentrasi yang mencapai puncak mortalitas dengan persentase $40 \%$. Hal ini diduga karena konsentrasi tersebut lebih tinggi dibandingkan dengan konsentrasi lainnya yaitu 20 g. $1^{-1}$ air $(17,5 \%), 40$ g. $1^{-1}$ air (22,5\%), 60 g. $1^{-1}$ air $(25 \%)$. Sesuai dengan hasil penelitian Hafiz (2013) bahwa semakin tinggi konsentrasi yang diberikan maka jumlah serangga yang mati juga semakin tinggi akibat senyawa asarone dari ekstrak rimpang jeringau yang masuk ke dalam tubuh serangga. Hal ini juga berkaitan dengan waktu awal kematian (Tabel 1) dimana perlakuan konsentrasi 80 g. $1^{-1}$ air menunjukkan waktu lebih cepat dalam mematikan nimfa walang sangit yaitu 1,25 jam. Perlakuan dengan konsentrasi tertinggi mengandung bahan aktif yang tinggi, sehingga daya racunnya juga tinggi dan semakin tinggi pula daya bunuh terhadap nimfa walang sangit. Sesuai dengan pendapat Mulyana (2002) bahwa pemberian konsentrasi yang tinggi menyebabkan serangga cepat mengalami kematian, hal ini disebabkan banyak zat aktif yang masuk ke dalam tubuh serangga.

Pengamatan pada hari kedua menunjukkan persentase kematian nimfa walang sangit terhadap semua perlakuan mengalami penurunan yaitu konsentrasi perlakuan 20 g..$^{-1}$ air (15\%), 40 g. $1^{-1}$ air $(12,5 \%)$, 60 g. $1^{-1}$ air (15\%) dan 80 g..$^{-1}$ air $(20 \%)$. Hal ini diduga daya kerja senyawa asarone ekstrak rimpang jeringau sudah mulai menurun sehingga mortalitas harian pada hari kedua menurun.

Pengamatan pada hari ketiga memperlihatkan bahwa semua perlakuan masih mampu membunuh nimfa walang sangit dengan persentase kematian berturut-turut $15 \%, 20 \%$, $22,5 \%$ dan $12,5 \%$. Hal ini diduga senyawa asarone yang masuk ke dalam tubuh walang sangit telah terakumulasi dengan baik sehingga mortalitas harian pada hari ketiga terlihat meningkat dibandingkan dengan mortalitas pada hari kedua.

Pengamatan pada hari keempat semua perlakuan mengalami penurunan mortalitas harian kecuali pada perlakuan konsentrasi 80 g. $l^{-1}$ air. Hal ini diduga karena senyawa asarone yang terkandung dalam ekstrak rimpang jeringau cepat terurai sehingga kemampuan dalam mematikan nimfa walang sangit menjadi menurun. Selain itu, jumlah nimfa walang 
sangit yang masih hidup lebih sedikit disebabkan puncak kematian telah terjadi pada hari sebelumnya, sehingga kematian pada hari keempat cenderung terlihat menurun.

\section{Mortalitas Total (\%)}

Hasil pengamatan persentase mortalitas total nimfa walang sangit setelah dianalisis menggunakan sidik ragam menunjukkan bahwa perlakuan konsentrasi ekstrak rimpang jeringau memberikan pengaruh nyata terhadap persentase mortalitas total nimfa walang sangit dan hasil uji lanjut DNMRT pada taraf 5\% dapat dilihat pada Tabel 3.

Tabel 3. Rata-rata mortalitas total nimfa walang sangit dengan perlakuan beberapa konsentrasi ekstrak rimpang jeringau (\%)

\begin{tabular}{cc}
\hline Konsentrasi ekstrak rimpang jeringau $\left(\mathrm{g}^{-1} \mathrm{I}^{-1}\right.$ air $)$ & Rata-rata mortalitas total nimfa walang sangit $(\%)$ \\
\hline 0 & $0,00 \mathrm{~d}$ \\
20 & $47,50 \mathrm{c}$ \\
40 & $57,50 \mathrm{~b}$ \\
60 & $65,00 \mathrm{~b}$ \\
80 & $87,50 \mathrm{a}$ \\
\hline
\end{tabular}

$\mathrm{KK}=11,48 \%$

Angka-angka pada lajur yg diikuti oleh huruf kecil yang tidak sama berbeda nyata menurut uji DNMRT pada taraf $5 \%$. Setelah ditransformasi dengan Arc Sin $\sqrt{y}$.

Tabel 3 menunjukkan bahwa perlakuan konsentrasi 80 g. $\mathrm{l}^{-1}$ air ekstrak rimpang jeringau mampu menyebabkan persentase mortalitas total nimfa walang sangit tertinggi sebesar $87,50 \%$ dan berbeda nyata dengan semua perlakuan. Hal ini juga berkaitan dengan waktu awal kematian dan $\mathrm{LT}_{50}$ nimfa walang sangit tercepat yaitu dengan waktu awal kematian selama 1,25 jam dan $\mathrm{LT}_{50}$ selama 30,25 jam dibandingkan dengan perlakuan lainnya. Hal ini diduga bahwa semakin tinggi konsentrasi yang digunakan maka semakin banyak senyawa asarone yang dihasilkan, semakin banyak ekstrak rimpang jeringau yang masuk ke dalam tubuh nimfa walang sangit akan menyebabkan semakin tinggi kematian nimfa walang sangit. Sesuai dengan pendapat Hindrayani et al. (2011) bahwa semakin tinggi konsentrasi yang diberikan maka jumlah racun yang mengenai kulit serangga semakin banyak sehingga meningkatkan efektifitas dan dapat menghambat pertumbuhan dan menyebabkan kematian serangga lebih banyak.

Hasil penelitian Hafiz (2013) menunjukkan bahwa konsentrasi ekstrak rimpang jeringau 50 g. $^{-1}$ air menghasilkan mortalitas total Myzus persicae sebesar 93,33\%, sedangkan mortalitas total nimfa walang sangit dengan ekstrak rimpang jeringau 80 g. l $^{-1}$ air cenderung lebih rendah yaitu $87,50 \%$. Hal ini diduga karena umur dan ukuran tubuh serangga yang berbeda. Pendapat ini sesuai dengan
Natawigena (1990) bahwa semakin panjang umur dan besar ukuran tubuh serangga maka semakin kuat daya tahan hidup serangga sehingga jumlah konsentrasi yang dibutuhkan untuk mematikan serangga tersebut juga tinggi.

Menurut Asikin dan Thamrin (2009) umur total periode nimfa walang sangit 19-27 hari, lebih lama dari umur total periode nimfa Myzus persicae hanya 16 hari (Direktorat Perlindungan Hortikultura, 2013). Sedangkan ukuran tubuh nimfa walang sangit yaitu 14-17 mm (Baharally dan Simon, 2014) lebih besar dari ukuran tubuh Myzus persicae hanya 1,8-2,3 $\mathrm{mm}$ (Direktorat Perlindungan Hortikultura, 2013).

Perlakuan konsentrasi 60 g. $\mathrm{l}^{-1}$ air menunjukkan persentase mortalitas total nimfa walang sangit sebesar $65 \%$ dan berbeda tidak nyata dengan konsentrasi 40 g. $\mathrm{l}^{-1}$ air sebesar $57,50 \%$ namun berbeda nyata dengan konsentrasi 20 g. $\mathrm{l}^{-1}$ air. Hal ini diduga pada perlakuan $60 \mathrm{~g} . \mathrm{l}^{-1}$ air adanya respon yang sama dengan perlakuan $40 \mathrm{~g} . \mathrm{l}^{-1}$ air sehingga peningkatan konsentrasi yang diberikan tidak menimbulkan perbedaan yang nyata dalam hal mematikan nimfa walang sangit.

Kandungan bahan kimia terpenting dalam rimpang jeringau adalah minyak atsiri. Komposisi minyak atsiri rimpang jeringau terdiri dari asarone (82\%), kolamenol (5\%), kolamen (4\%), kolameone (1\%), metil eugenol (1\%) dan eugenol $(0,3 \%)$. Senyawa asarone 
masuk ke dalam tubuh serangga sebagai racun kontak dan racun perut. Racun kontak masuk melalui lubang-lubang alami pada serangga sedangkan racun perut masuk ke dalam tubuh serangga melalui proses makan dengan menghisap cairan pada bulir padi yang telah disemprot dengan ekstrak rimpang jeringau. Setelah masuk ke dalam tubuh nimfa walang sangit senyawa ini bekerja sebagai racun saraf sehingga dapat mengganggu aktifitas serangga yang dapat menyebabkan kematian pada serangga.

Menurut Simanjorang (2008) bahwa senyawa asarone yang masuk ke dalam tubuh serangga dapat menghambat respirasi sel dan berdampak pada jaringan saraf dan sel otot serangga yang berhubungan dengan gerak akibatnya serangga melemah, tidak aktif dan akhirnya mengalami kematian. Hal ini didukung oleh Nismah et al. (2011) bahwa senyawa toksik yang masuk ke dalam tubuh serangga akan mempengaruhi metabolisme dalam tubuhnya. Proses metabolisme tersebut membutuhkan energi, semakin banyak senyawa racun yang masuk ke dalam tubuh serangga maka semakin besar energi yang dibutuhkan untuk menetralisir senyawa racun tersebut sehingga serangga akan kekurangan energi dan akhirnya mati.

Konsentrasi ekstrak rimpang jeringau yang efektif digunakan dalam mengendalikan nimfa walang sangit adalah perlakuan konsentrasi $80 \quad$ g. $1^{-1}$ air karena mampu mematikan nimfa walang sangit sebesar $87,50 \%$. Pendapat ini sesuai dengan pernyataan Prijiono (2008) yang menyatakan bahwa suatu ekstrak dikatakan efektif sebagai pestisida nabati apabila suatu perlakuan dengan ekstrak tersebut dapat mengakibatkan tingkat kematian serangga uji lebih dari $80 \%$.

\section{KESIMPULAN DAN SARAN}

\section{Kesimpulan}

Uji beberapa konsentrasi ekstrak rimpang jeringau (Acorus calamus L.) terhadap walang sangit pada tanaman padi gogo diperoleh kesimpulan bahwa perlakuan konsentrasi 80 g.1 - $^{-}$ ${ }^{1}$ air merupakan konsentrasi yang efektif untuk mengendalikan hama walang sangit dimana pada konsentrasi ini dapat menyebabkan mortalitas total sebesar $87,50 \%$ dengan awal kematian 1,25 jam setelah aplikasi dan $\mathrm{LT}_{50}$ pada jam ke 30,25 setelah aplikasi.

\section{Saran}

Berdasarkan hasil penelitian yang telah dilakukan pada uji beberapa konsentrasi ekstrak rimpang jeringau (Acorus calamus L.) terhadap walang sangit disarankan menggunakan konsentrasi 80 g. $l^{-1}$ air untuk mengendalikan nimfa walang sangit, karena dapat menyebabkan mortalitas total sebesar $87,50 \%$.

\section{DAFTAR PUSTAKA}

Aminah, S. N. 1995. Evaluasi Tiga Jenis Tumbuhan sebagai Insektisida dan Repelan terhadap Nyamuk di Laboratorium. Tesis (Tidak dipublikasikan). Institut Pertanian Bogor. Bogor.

Asikin, S. dan M. Thamrin. 2009. Pengendalian hama walang sangit (Leptocorisa acuta T.) di tingkat petani lahan rawa lebak. Dalam Qomarodin (peny.). Temu Teknis Nasional Tenaga Fungsional Pertanian. Balai Penelitian Pertanian Lahan Rawa (Ballittra). Kalimantan Selatan: 377-380.

Badan Pusat Statistik (BPS) Riau. 2017. Luas Panen, Produktivitas dan Produksi Padi Riau, 2013-2015. https://riau.bps.go.id/statictable/2017/01/ 16/235/-luas-panen-produktivitas-danproduksi-padi-riau-2013-2015.html. Diakses tanggal 15 Mei 2018.

Baharally, V., and S. Simon. 2014. Biological studies on gundhi bug, Leptocorisa acuta T. (Hemiptera: Alydidae) under allahab, uttar pradesh (UP), India. International Jurnal of Agricultural. 4(3): 57-62.

Dewi, R. S. 2010. Keefektifan Tiga Jenis Tumbuhan Terhadap Paracoccus marginatus dan Tetraychus sp. pada Tanaman Jarak Pagar (Jatropha curcas L.). Tesis (Tidak dipublikasikan). Institut Pertanian Bogor. Bogor.

Direktorat Perlindungan Hortikultura. 2013. Kutu Daun-OPT Sayur-Cabai. http://ditlin.hortikultur a.pertanian.go.id/index.php?option $=\mathrm{com}_{-}$ content $\&$ view $=$ article $\& i d=83 \&$ Itemid $=2$ 07. Diakses tanggal 25 November 2018. 
Farida, I. N. 2008. Efektivitas Ekstrak Rimpang Dringo (Acorus calamus L.) terhadap Mortalitas Larva Spodoptera litura F. Skripsi (Tidak dipublikasikan). Universitas Jember. Jember.

Hafiz, M. A. 2013. Uji Beberapa Konsentrasi Ekstrak Rimpang Jeringau (Acorus calamus L.) untuk Mengendalikan Hama Kutu Daun Myzus persicae Sulzer pada Tanaman Cabai (Capcicum annum L.). Skripsi (Tidak dipublikasikan). Universitas Riau. Pekanbaru.

Haryanto, T. A. D., Suwarto, Sunarto, Daryanto dan L. Susanto. 2003. Perakitan Varietas Unggul Padi Gogo Berdaya Hasil Tinggi dan Aromatis untuk Meningkatkan Produksi dan Nilai Ekonomi Padi Gogo. Laporan Penelitian (Tidak dipublikasikan). Universitas Jenderal Soedirman. Purwokerto.

Hindrayani, M., Busniah dan Safriadi. 2011. Potensi ekstrak lada hitam Piper nigrum L. (Piperaceae) sebagai pestisisda nabati untuk pengendalian wereng batang coklat Nilaparvata lugens Stal. (Homoptera; Delphacidae). Jurnal Manggaro. 12(2): 64-70.

Mulyana. 2002. Ekstraksi Senyawa Aktif Alkaloid, Kuinon dan Saponin dari Tumbuhan Kecubung sebagai Larvasida dan Insektisida terhadap Aedes agypti. Skripsi (Tidak dipublikasikan). Institut Pertanian Bogor. Bogor.

Natawigena, H. 1993. Entomologi Pertanian. Penerbit Orba Shakti. Bandung.

Nismah, N., Utami dan G. D. Pratami. 2011. Isolasi senyawa Flavonoid dari ekstrak air serbuk daun gamal (Gliricidia maculata) dan uji toksisitas terhadap hama kutu putih pepaya (Paracoccus marginatus). Pusat Penelitian dan Pengembangan Tanaman. Disampaikan pada Seminar Nasional Perhimpunan Entomologi Indonesia Cabang Bandung. 10-12 Februari 2011. Bandung.

Nursal, E., P. S. Sudharto dan R. D. D. Chenon. 1997. Pengaruh Konsentrasi Ekstrak Bahan Pestisida Nabati Terhadap Hama. Balai Penelitian Tanaman Obat. Bogor.

Pandey, U. K., V. Pandey and P. Singh. 2005. Response of some plants origin insecticides against $S$. litura (Tobacco caterpillar) infesting some food plants. In
Environment and Toxicology (Kumar, A. ed) A. P. H. Publishing Corporation. 9193. New Delhi.

Perdana, A. P. 2010. Budidaya Padi Gogo. Penebar Swadaya. Jakarta.

Prijino, D. 2002. Pengujian Keefektifan Campuran Insektisida: Pedoman bagi Pelaksanaan Pengujian Efikasi untuk Pendaftaran Pestisida. Institut Pertanian Bogor. Bogor.

Prijino, D. 2008. Insektisida Nabati: Prinsip, Pemanfaatan dan Pengembangan. Departemen Proteksi Tanaman. Institut Pertanian Bogor. Bogor.

Simanjorang, J. 2008. Efektivitas Rimpang Jeringau (Acorus calamus L.) dalam Membunuh Nyamuk Aedes aegypti. Skripsi (Tidak dipublikasikan). Universitas Sumatera Utara. Medan.

Syakir, M. 2011. Bintaro (Cerbera manghas) sebagai pestisida nabati. Pusat Penelitian dan Pengembangan Tanaman Perkebunan. Disampaikan pada Seminar Nasional Pestisida Nabati IV. 15 Oktober 2011. Jakarta.

Tarumingkeng, R. C. 1992. Insektisida: Sifat, Mekanisme Kerja dan Dampak Penggunaannya. Kanisius. Yogyakarta. 
